\title{
Integration of online Teaching Resources of University Ideological and Political Theory Course in the Era of Big Data
}

\author{
HONG Yan \\ Liaoning Police Academy, Dalian, China.
}

\begin{abstract}
In the era of big data, the integration of online teaching resources of university ideological and political theory courses is confronted with challenges' of large amount of data, diversity and the hide of the value. To take the opportunity and meet the challenges, we should clarify the connotation and components of the integration of online teaching resources of university ideological and political theory courses, following three integration principles. The guideline for the integration of online teaching resources of university ideological and political theory courses lies in integrating three different levels of teaching objectives: competence, knowledge and quality into three corresponding resource modules to enrich online teaching resources, so as to improve the effects of university ideological and political theory courses online teaching.
\end{abstract}

Keywords -Big Data era, university ideological and political theory courses, online teaching, resources integration

\section{INTRODUCTION}

With the development of information and communication technology, web technology has been a widespread and effective way to support online teaching of university ideological and political theory courses ( hereafter referred to as ideological and political course). Ideological and political teachers should change their minds promptly and adapt to the needs of Big Data era, rationally analyze and utilize the huge and complicated online data resources, integrate online teaching resources and construct online teaching recourse platforms of ideological and political course.

\section{CHALLENGES UNIVERSITY IDEOLOGICAL AND POLITICAL TEACHERS MEET IN INTEGRATING ONLINE TEACHING RESOURCES OF UNIVERSITY IDEOLOGICAL AND POLITICAL THEORY COURSE IN THE ERA OF BIG DATA}

2.1 Characteristics and connotation of big data

Big data usually includes data sets with sizes beyond the ability of commonly used software tools to capture, curate, manage, and process data within a tolerable elapsed time. [1] Big data can be described by the following characteristics: [2] Volume: The quantity of generated and stored data. The size of the data determines the value and potential insight- and whether it can actually be considered big data or not. Variety: The type and nature of the data. This helps people who analyze it to effectively use the resulting insight. Velocity: In this context, the speed at which the data is generated and processed to meet the demands and challenges that lie in the path of growth and development. Variability: Inconsistency of the data set can hamper processes to handle and manage it. Veracity: The quality of captured data can vary greatly, affecting accurate analysis.

2.2 Challenges University Teachers Meet in the era of big data in integrating Online Teaching Resources of Ideological and Political Courses.

Judging from the characteristics and connotation of the big data, the online teaching resources are bound to be enormous and complicated, the potential challenges include: (1) the challenges of data quantity. With more and more data coming into the data base, students might read some inaccurate, even wrong, or useless information (2) the challenges of the data variety. The presentation of the data is multiple and various, like in the form of photo, words, audio or video, on the other hand, videos of phonograph, violence or superstition, even values or life styles of capitalism publicized by the western countries might influence the fostering of right values, which needs the teachers of ideological and political courses to improve self-cognition capability and leading ability to integrate and edit effectively each resource. (3) the challenges of the potential values of the big data. New knowledge, new wisdom, new value can be found and improved through the 
exchange, integration and analysis of big data. It's difficult for teachers of ideological and political course to select and take useful online teaching resources out of the constantly changing data, at present, most of the teachers of ideological and political course can't collect, store, analyze and present the big data, can't use data analysis technology, or integrate and explore the potential value of the big dat. It's more difficult for them to make full use of these selected resources to better and more effectively direct the students to apply principles and viewpoints of Marxism to understand and solve practical problems so as to help them establish the core value of socialism.

\section{THE CONNOTATION AND CONSTITUTION OF INTEGRATED ONLINE TEACHING RESOURCES OF UNIVERSITY IDEOLOGICAL AND POLITICAL THEORY COURSE IN THE ERA OF BIG DATA}

In the era of big data, it is required that instructors of ideological and political theory course should dig into and absorb online teaching resources from enormous data with low density of values. The priority is put on the connotation of integrated online teaching resources for this course, defining their types and scopes

3.1 The connotation of integrated teaching resources in university ideological and political theory course

The integration of online teaching resources for this course is aimed at enhancing students' moral quality, intellect quality and capability quality with the guidance of establishing the socialist core values by means of selecting and utilizing valuable online teaching resources from enormous network resources in form of image, text, audio and video ones. The purpose is to integrate those resources in order to meet the requirements of the college students and possess the network resources modules with the specialty of ideological and political theory education, which is beneficial to improve students' comprehensive qualities, contributing to increasing effectiveness and realizing tri-leveled teaching objects in knowledge, capability and quality.

3.2 The constitution of online teaching resources of university ideological and political theory course

Online teaching resources of college ideological and political theory course contain various resources such as knowledge, intelligence information, material, information, image, text, latest information which provide good materials for online teaching. According to the current construction situation of online teaching in ideological and political theory course and the current technical manual for educational resource construction, the teaching resources contain the following systems and functional data: Teaching Support System, Online Course Database, and Multi-media Material Database. The Teaching Support System contains the following functions: coaching and answering, homework mark, distance exams, teaching models management, question bank management, online searching, communicative discussion tool and teaching and research search engines. Online Course Database contains courseware inhaul, question bank, document literature, case study, etc. The Multi-media Material Database includes text, image, animation cartoon, voice frequency, video frequency, archive online course and archive management system of teaching resources. Online audio and video teaching resources, the multi-media online courseware resources, the information communication resources with online forum as the platform and online digital library resources all play important roles in online teaching resources of college ideological and political theory course. Fig. 1 depicts the details of these three components of the whole online teaching resources.

The Teaching Support System is the foundation of online teaching; the Online Course Database is the extension of the knowledge points; the Multi-media Material Database provides vivid audio and video materials to enrich teaching, being as the complementary part of online teaching. These three parts integration constitutes the complete online teaching resources system. After finishing learning the basic knowledge on the Teaching Support System, the students continue to learn the knowledge points deeply through the Online Course Database. The Multi-media Material Database is the most joyful teaching carrier to motivate learning interests and inspire learning enthusiasm, which contributes to the enhancement of the pertinence and effectiveness of the teaching practice. 


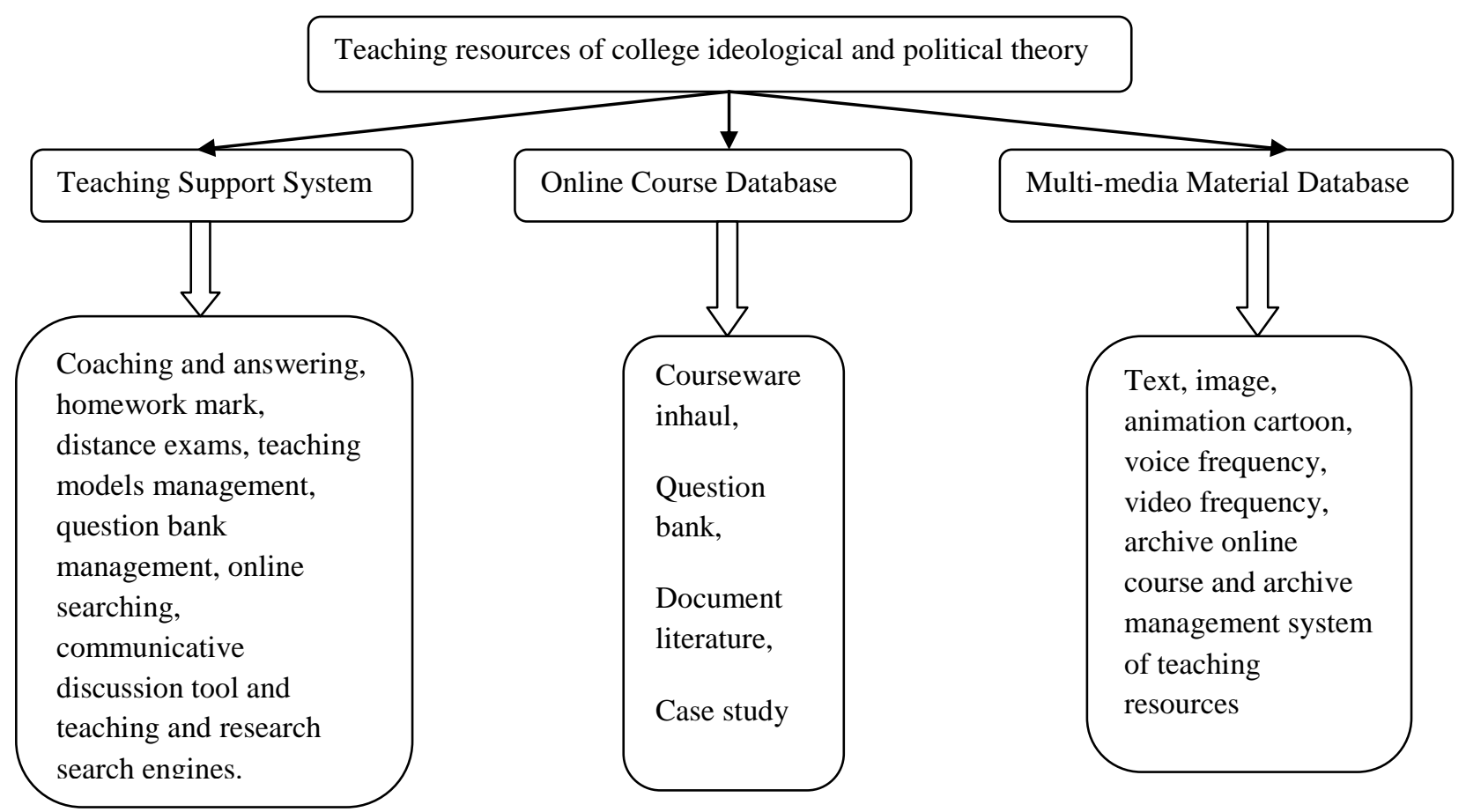

Fig. 1: The constitutions of online teaching resources of ideological and political theory course

\section{THE PRINCIPLE AND PRACTICE OF INTEGRATING ONLINE TEACHING RESOURCES OF IDEOLOGICAL AND POLITICAL THEORY COURSE IN DIFFERENT LEVELS}

The integration of online teaching resources aimed at improving college students' qualities should base on the development requirements of the students and the educational demands, integrating the resources possessing educational functions into one teaching module. The integration thinking of network teaching resources focuses on such three-leveled teaching objects as capability object, knowledge object, and quality object. On the basis of adhering to the scientific principles, we should integrate these valuable online teaching resources in different levels.

4.1 The followed principles on integrating online teaching resources of ideological and political theory course

Combination of initiative and guidance: In the era of big data, various and enormous information strikes our eyeballs and brains because of the spurt of network technology and popularity. On receiving the mainstream ideology education, the students are affected by that non-mainstream, or even reactionary information. Most of the young students are not equipped with the abilities to select this information, and just at this moment, our ideology educators should play their guiding roles to resist those cultural rubbish and malicious information, providing a positive and vigorous network environment for ideological and political theory teaching.

Combination of scientificity and adaptation: The scientific principle refers to the scientific design of teaching objects and contents on integrating online teaching resources, selecting theoretical knowledge which conforms to the reality of ideological and political course to spread. Two points are important to focus on: to make a judgment about online teaching resources with the purpose of eliminating the false and retaining the true to ensure solid resources with scientific basis; to select essence from massive online resources, searching the highlights of materials to guarantee teaching effects. While sticking to the scientific principle on constructing online resources, we should reflect the adaptation principle which indicates the resources adapting to college students' characteristics of body and mind, and their knowledge structure. There are also two points to pay attention to: to select online teaching resources closed to students' reality; to study the focus, interests and difficult points of college classrooms in order to increase pertinence of online classroom

Sharing and dynamic development: Instructors of ideological and political theory course should realize co-building and sharing of online teaching resources, fulfilling integration of teaching resources together 
through sharing out the work and cooperating with each other, which shares the common production and avoids rehandling so as to promote working efficiency. Instructors also co-construct and share online teaching resources with students, inspiring them to upload suitable resources through network platform and turn into teaching resources after instructors' review and regulation so as to update resources in order to realize dynamic development of online teaching resources, which promotes students' initiative and enthusiasm in learning this course.

4.2 The practice of integrating online teaching resources in different levels

Knowledge resource module: Because theoretical knowledge of ideological and political theory course has different focus, this course mainly depends on four courses: Ideological and Moral Cultivation and Legal Basis, Outline of Chinese Modern History, Introduction to Maoism and Theoretical System of Socialism with Chinese Characteristics, and Basic Principle of Marxism, and builds different knowledge modules with particular focus. The College Students' Training Center of Psychological and Moral Education in ideology and Online Research and Training Office can be built. Theoretical teaching resources can be shared online including syllabus, curriculum standards, teaching courseware, teaching materials, teaching cases, test papers resources, reading list, and practical requirements. Instructors and students rely on this supporting system to fulfill teaching and learning process, integrating these resources to form a complete knowledge resource module from which students can develop self-study to take the shape of online research and training.

Moral education resource module: Instructors are responsible in searching all kinds of media resources of their course, collecting the relevant catalogue indexing and establishing teacher-to-student communication platform. Instructors take this platform as the vital supplementary means of classroom teaching, which not only realizes web-mediated, digitalized course recourses, but also provides a sharing platform for question discussion, online answering, online assignment, online test, and teaching resource release. In the process of communication between teacher and student, the students are inspired, enhancing their ideological and moral qualities along with the inspiration. Take the course of Ideological and Moral Cultivation and Legal Basis as an example, instructors upload those philosophic essays, well-known sayings, great figure's biographies, and case videos to interact and discuss with students through WeChat, Micro Blog, or QQ so as to enhance their morality. Meanwhile, instructors choose such mainstream websites resources as People's Daily and Xinhua net, selecting special columns fit for morality education as learning resources.

Capability and quality resource module: Instructors, on one hand, learn about students' focus of online information to initiate discussion and grasp their value judgment about information, [3] and on the other hand, integrate the feedback information, the focus, the interest, or the confusing points from the students into knowledge points, and then sort out audio and video online resources relevant to knowledge points, making analytical comparison and judgment on teaching practice. It is just in this process that the students come to understand the theoretical knowledge of Marxism with improving resolution capability, aesthetic judgment and critical thinking skills. In addition, the teaching process of integrating and sorting out online teaching resources can be made a micro-class to be uploaded into online course database of ideological and political theory, which not only realizes the sharing of excellent teaching resources, but also plays the leading role in guiding the students to keep improving themselves in ideology and morality.

\section{REFERENCES}

[1] Snijders, C., Matzat, U., Reips, U.-D., 'Big Data': Big gaps of knowledge in the field of Internet, International Journal of Internet Science Theory, (7), 2012, 1-5.

[2] Hilbert, Martin. Big Data for Development: A Review of Promises and Challenges. Development Policy Review. Martinhilbert.net. Retrieved October 7, 2015.

[3] Liang Jiafeng, Qi Zhenhua. Ideological and political education in college in the era of big data. Studies in Ideological Education, (6), 2013. 